\title{
Research on the Teaching Reform of College English Translation Under the Background of Curriculum Ideology and Politics
}

\author{
Fanting Meng* \\ School of Western Languages and Cultures, Harbin Normal University, Harbin 150001, Heilongjiang Province, China \\ *Corresponding author: Fanting Meng, 39885082@qq.com
}

\begin{abstract}
Curriculum ideology" is a new teaching concept that combines professional courses with ideological and political courses. At present, the teaching reform of ideological and political education has been launched in colleges and universities across the country. It is a major innovation in the field of education in the new era. With the continuous improvement of China's opening to the outside world, there is also a strong demand for applied foreign language talents. As a course with elements of cross-cultural knowledge and foreign cultural system, college English translation must adapt to the macro requirements of the ideological and political concepts of college English courses as well as reform its teaching contents and methods. On this basis, this article analyzes the status quo of college English translation under the background of "curriculum ideology" and proposes ways to reform the teaching of college English translation, in order to break the limitations of traditional college English teaching, improve students' learning efficiency, and further deepen the reform of translation teaching, and cultivate modern applied cross-cultural communication talents with high professional skills and political literacy.
\end{abstract}

Keywords: Curriculum ideology; College English; English translation; Teaching reform

Publication date: December 2021; Online publication: December 23, 2021

\section{Introduction}

In 2014, the Shanghai Municipal Committee and Municipal Government took the lead in proposing the concept of "curriculum ideology," aiming to effectively combine ideological and political education with the teaching of various disciplines, so as to achieve the goal of moral education and improve the teaching effect ${ }^{[1]}$. In December 2016, at the National Conference on University Ideological and Political Work, it was pointed out that we must make full use of the main channels of classroom teaching, adhere to the improvement of ideological and political courses, enhance the affinity and pertinence of ideological and political education, as well as meet the needs of students' growth and development; with expectations, other courses must maintain a good channel and plant a good field of responsibility, so that various courses and ideological and political theories can advance in the same direction and form a synergistic effect ${ }^{[2]}$. In August 2019, the General Office of the State Council issued the Opinions on Deepening the Reform and Innovation of Ideological and Political Theory Courses in Schools in the New Era, proposing to build a batch of ideological and political model higher education, set up a batch of ideological and political model courses, as well as select a batch of ideological and political teachers and teaching teams. Moral construction and talent construction run through the whole process of college classroom teaching ${ }^{[3]}$. At present, the main task and challenge faced by Chinese universities is on how to scientifically and effectively combine curriculum ideological and political education with curriculum teaching. 
As a course closely related to foreign culture, college English translation has a special potential for ideological and political education from a cross-cultural perspective. Therefore, in recent years, there has been an active expansion of the ideological and political functions in the teaching of college English translation. While achieving the primary task of English translation teaching through the transformation of educational content, form, and methods, there is a strive to steadily improve the quality and effectiveness of college ideological and political education.

\section{Connotation of "curriculum ideology"}

"Curriculum ideology" is a new educational concept in today's era. At present, colleges and universities across the country have successively launched the teaching reform of "curriculum ideology." The curriculum carries ideological and political education, and ideological and political education is in the course teaching. "Curriculum ideology" assumes "building up morality and cultivating people" as the fundamental task of education. Through the organic combination of professional courses with ideological and political courses, a fully-staffed, full-process, full-course, and all-round education model comes into being ${ }^{[4]}$. The basic construction of "curriculum ideology" lies in the construction of the "curriculum". Therefore, in the course of curriculum construction, it is necessary to pay attention to the core position of ideological and political education in the curriculum teaching and the information of ideological and political education in the content of the course. The combination of many aspects can promote the expansion of curriculum teaching from a single professional knowledge education to a "knowledge and moral quality" education, promote the unity of subject knowledge and humanistic quality, and help students establish a correct outlook on life, world outlook, and values.

\section{Status quo of research on English translation teaching in colleges and universities}

At present, college English teaching often only focuses on the teaching of professional knowledge, lacking the guidance and education of ideological and political concepts for students. There are also many similar problems in translation teaching.

The first is the weakening of humanistic education goals in translation teaching. At present, the teaching of college English translation one-sidedly focuses on the application of translation strategies, the teaching of translation theories, and the cultivation of bilingual conversion capabilities. On the other hand, ideological and political education has not been of significance in translation teaching. Teachers cannot consciously explore the ideological and political factors in the teaching content and eliminate the single concept of curriculum knowledge.

In the actual teaching of college English translation, teachers lack the awareness of ideological and political education, which causes students to excessively emphasize on the learning of professional knowledge but lack the thinking about values. No matter what kind of language, it is far from enough to focus on the language level. The teaching of translation should mainly be discussed from two aspects: cultural connotation and values.

In addition, there is a lack of thinking about the ideological and political teaching in English translation courses. Colleges and universities should give full play to the leading role of "discipline ideological and political" teaching and carry out ideological and political teaching in college English translation courses. First, teachers need to clarify the logical relationship between the main channels of "curriculum ideology" teaching and English translation courses, so that "curriculum ideology" becomes the source of the teaching reform. Secondly, there is a lack of scientific and reasonable construction in the teaching mechanism of college English translation. This includes the construction of a sustainable teaching mechanism for school organization and management, professional construction, team building, teacher development, teaching 
evaluation, etc. Finally, there is still a lack of guidance from teachers in linking theory with practice in the teaching of college English translation. By exerting the leading role of "curriculum ideology" in the teaching of English translation, a typical teaching example for English translation can be formed ${ }^{[5]}$.

\section{The reform requirements of college English translation teaching in the context of curriculum ideology and politics}

\subsection{Maintaining a certain degree of difficulty in teaching and strengthening students' translation skills}

The goal of teaching English translation is to train more high-quality talents and outstanding talents with good political literacy and values for the country's external development. From the perspective of a value scale, the country has the same requirements for English translators in terms of "professional quality" and "political quality," reflecting the equal importance of the two aspects. In other words, the improvement of college English translation teaching can strengthen the core of internal ideology and politics, but it should not be based on reducing the intensity and difficulty of teaching; that is to say, in order to achieve the goal of ideological and political education, inappropriate contents should not be incorporated into teaching, but the selection of all educational activities and educational contents must be the best solution for the integration of professional quality and political quality ${ }^{[6]}$.

\subsection{Strengthening teachers' ideological and political concepts and improving teachers' awareness of "curriculum ideology" education}

Experts have pointed out that in order to achieve a link in theory and practice between ideological and political courses with other courses, ideological and political education should not only be the responsibility of the ideological and political team, but also each and every teacher. It is necessary to fully coordinate and play the role of professional teachers, full-time personnel, and part-time personnel in the ideological and political team, highlighting their respective advantages ${ }^{[7]}$. This requires colleges and universities to pay attention to the cultivation of "curriculum ideology" awareness, including English translation teachers. At the same time, teachers themselves must keep pace with the times, deeply understand the connotation and teaching concepts of "curriculum ideology," use curriculum ideological and political theories as well as teaching methods to improve students' ideological and political quality, flexibly infiltrate ideological and political lessons into classroom teaching, consciously become an excellent disseminator of Chinese and Western cultures and ideas, as well as play a guiding role in the growth of students.

\subsection{Avoiding the blind worship of cultures from other countries, and building up the country's cultural self-confidence}

In the teaching process of college English translation, some foreign cultures, such as popular culture, historical culture, etc., are often involved. Students have an interest in these popular cultures. Some English teachers have mastered the students' psychology and are actively sharing this information in the teaching process. However, once the teachers' teaching standards are not in place, it would lead to a tendency to worship the culture of other countries in the selection and teaching process, thus leaving a subtle impact on the students. Therefore, based on the political education requirements conveyed by the concept of "curriculum ideology" and the basic principles that "English translation teaching serves the country's development," the teaching of college English translation needs to avoid the influence from other countries under the guidance of "curriculum ideology" education ${ }^{[6]}$. The cultural worship in China, through cultural contrast, highlights the unique charm of the country's culture and builds up the country's cultural selfconfidence. 


\section{The reform and practice of college English translation teaching under the background of curriculum ideology and politics}

\subsection{Improve students' political literacy by using trending news}

After students have mastered the "English to Chinese" skill, which needs to be learned in class through practice, teachers can further explain the "Chinese to English" skill. "Chinese to English" translation can be regarded as the output of a language ${ }^{[6]}$. Teachers can appropriately integrate trending news on Sinoforeign cultural exchanges as thematic materials to stimulate students' interest and allow students to give full play to their initiative. On the basis of consolidating their own political values, they should be proficient in English translation skills and strengthen the spirit of patriotism, thereby forming good political and English translation cultural qualities.

\subsection{Actively promote second classroom, strengthen patriotism education and national pride, as well as spread excellent traditional culture}

The integration of college English translation teaching and "curriculum ideology" education can use the advantages of the second classroom to build a comprehensive and multi-angle curriculum ideological and political system. In order to promote teaching, competitions can be held; this includes organizing and holding diversified competitions, such as Chinese and Western cultural translation competitions. The content of these translation competitions should include diplomatic activities, such as the reporting styles, representative cultural works, and other related content. In tutoring students to prepare them for competitions, teachers need to consciously guide students to rationally sort out the opinions and thoughts in these articles. In the evaluation stage, in addition to evaluating the overall quality of the translated work, teachers should also consider whether the students are able to display scientific and dialectical critical views through their works and whether the students are able to firmly maintain the socialist ideology. At the same time, these competitions would also help to promote China's excellent traditional culture.

\subsection{Innovate English translation teaching methods to enhance the effect of ideological and political education}

In this information age, online and offline teaching methods can be used in the teaching of English translation to pique students' interest in learning. There are many network platforms for online teaching, including Massive Open Online Courses (MOOCs) and NetEase Open Courses, which provide an important carrier for teachers to carry out English translation teaching and at the same time enrich the teaching methods of integrating ideological and political education into English translation classes ${ }^{[8]}$. Teachers can flexibly use online teaching to combine Western culture with the excellent traditional Chinese culture. In addition, teachers can also organize visits to various sites that reflect the excellent traditional Chinese culture, so that students realize that learning is not only focused on professional knowledge, but also the understanding of the traditional Chinese culture. In order to integrate ideological and political education into college English translation teaching, a student-centered classroom should be promoted. Rather than dominating the entire classroom, teachers should guide students' learning. Under this teaching mode, the enthusiasm and creativity of students can be stimulated; in addition, students would be able to truly learn to think independently as well as explore the knowledge and profound truths contained in their textbooks. In this manner, teachers can encourage students to learn traditional culture, guide students to establish correct values, outlook on life, and world outlook, as well as assist students in understanding the importance of ideological and political education and the significance of integrating ideological and political education into English translation teaching. 


\subsection{Diversified evaluations and teaching reflections on reforming English translation teaching}

In the process of incorporating ideological and political content into translation teaching, it is necessary to reform the old evaluation method in English translation teaching and introduce diversified evaluation forms. Students should be evaluated from different angles and aspects. For example, in English translation teaching, the evaluation criteria for students should not be limited to the degree of mastery of translation theory and knowledge or the formative evaluation of translation practice performance; on the contrary, the evaluation should be organically combined with the evaluation of ideological and political ability. Students should not only focus on learning knowledge and improving their professional skills, but also on improving their moral qualities. Specifically, the evaluation should include students' goal setting, self-management, learning attitude, classroom performance, bilingual ability, thought process, as well as their humanistic and moral quality in the learning process ${ }^{[10]}$. A comprehensive evaluation involves multiple evaluation methods, such as student mutual evaluation and self-evaluation, to ensure that the evaluation process is fair and reasonable, as well as to achieve a win-win situation in teaching and learning [9].

Teachers should also reflect through evaluation about whether the educational and teaching goals have been achieved, whether their words and deeds play a positive role in guiding the students, whether the teaching content has been mastered by the students, whether the student management is in place, and whether the students are developing healthily, so as to improve the teaching design and implementation strategies in schools ${ }^{[10]}$. The reflection on English translation teaching mainly scrutinizes whether the teaching process enhances the knowledge, ability, and teaching goals of political literacy, students' classroom performance, as well as knowledge feedback; in addition, it also investigates whether the translation theories and strategies learned can be flexibly applied in practice and whether ideological and political education runs throughout the whole process. Teachers should insist on reflective teaching in order to better improve the way classes are being carried out.

\section{Conclusion}

The teaching of college English translation is responsible for the important task of cultivating outstanding applied foreign language talents. It does not only cultivate students' professional knowledge and skills, but also improve their bilingual ability and actively integrate ideological and political education into college English translation classes. It enriches the teaching mode in translation classes, mobilizes the enthusiasm of students and teachers in teaching, as well as enhance patriotic enthusiasm and national cultural pride. At the same time, this integrated reform is also in line with the law of market development and the mode of teaching reform. It can improve the moral, cultural, and knowledge literacy of students as well as achieve the goal of "building up morality and cultivating people" in the teaching of English translation, thereby cultivating more outstanding talents and successors for the society and the country as well as laying a solid foundation for the realization of the Chinese dream of the great rejuvenation of the Chinese nation.

\section{Funding}

This study was supported by the Economic and Social Development Research Project in Heilongjiang Province (2019) - A Feminist Study of American Fiction Writing in the 20th Century (WY2019022-B) and the General Research Project of Higher Education Reform in Heilongjiang Province (2019) - Subjects' Communication System in Translation Teaching for English Majors (SJGY20190373).

\section{Disclosure statement}

The author declares that there is no conflict of interest. 


\section{References}

[1] Song K, 2021, On the Reform Strategy of College English Teaching Under the Background of Curriculum Ideology and Politics. Campus English, 2021(36): 37-38.

[2] Tian H, Fu H, 2018, Curriculum Ideological and Political: The Practical Path of Integrating the Teaching of Professional Courses in Colleges and Universities into Ideological and Political Education. Future and Development, 2018(4).

[3] Wang X, 2020, Exploration of the Implementation Path of the Teaching Reform of English Interpretation Courses in Local Colleges and Universities from the Perspective of Curriculum Ideology and Politics. Modern English, 2020(17): 39-41.

[4] Guo A, 2019, Research on College English Teaching Reform under the Background of "Curriculum Ideology and Politics”. Journal of Inner Mongolia University of Finance and Economics, 17(05): 138140 .

[5] Liao X, 2020, Practical Exploration of College English Translation Teaching Reform from the Perspective of Curriculum Ideology. Overseas English, 2020(12): 18-19, 25.

[6] Zeng D, 2021, Research on the Teaching Reform Strategy of "Curriculum Ideology and Politics" in College English. Campus English, 2021(6): 41-43.

[7] Zhang L, 2021, Practice Research on College English Translation Teaching Reform Under the Background of Curriculum Ideology and Politics. Modern Vocational Education, 2021(33): 8-9.

[8] Li J, 2017, “Three Combinations" Promote Ideological and Political Work in Colleges and Universities. Research on Ideological and Political Work, 2017(9): 30-32.

[9] Lu H, 2021, Exploration of College English Translation Teaching Reform Strategies Based on Curriculum Ideological and Political Perspectives. Overseas English, 2021(15): 200-201.

[10] Jin X, 2019, Exploration of the Implementation Strategies of "Curriculum Ideology and Politics" in College English Teaching. Journal of Mudanjiang Institute of Education, 2019(11): 61-63. 